Article

\title{
Efficiency Assessment of Inbound Tourist Service Using Data Envelopment Analysis
}

\author{
Han-Shen Chen ${ }^{1}$ (1) , Bi-Kun Tsai ${ }^{2}$, Gwo-Bao Liou ${ }^{3}$ (D) and Chi-Ming Hsieh ${ }^{4, *(1)}$ \\ 1 Department of Health Diet and Industry Management, Chung Shan Medical University, No. 110, \\ Sec. 1, Jianguo N. Rd., Taichung City 40201, Taiwan; allen975@csmu.edu.tw \\ 2 Graduate Institute of Bio-Industry Management, National Chung Hsing University, 145 Xingda Rd., \\ South Dist., Taichung City 40227, Taiwan; pktsai@dragon.nchu.edu.tw \\ 3 School of Liberal Education, Shin Chien University Kaoshiung Campus, No. 200, University Rd., \\ Neiman Dist., Kaoshiung City 845, Taiwan; assure2012@gmail.com \\ 4 International Bachelor Program of Agribusiness, National Chung Hsing University, 145 Xingda Rd., \\ South Dist., Taichung City 40227, Taiwan \\ * Correspondence: hsiehch9@gms.ndhu.edu.tw; Tel.: +886-4-2284-0849 (ext. 622)
}

Received: 13 May 2018; Accepted: 1 June 2018; Published: 4 June 2018

\begin{abstract}
The successful and sustainable development of inbound tourism necessitates a long-term commitment, balancing between tourism supply and tourist demands. This study manipulated a performance appraisal of tourism service quality in Taiwan with Data Envelopment Analysis (DEA) by employing input and output constructs to assess service quality efficiency. The empirical results of the estimation of technical efficiency (TE) revealed that (1) the domestic tourism market is competitive, but still needs enhancements for tourism service; (2) Mainland Chinese tourists had the highest score among all foreign tourists, followed by Hong Kong and Macau tourists, tourists from other countries, Japanese tourists, and South Korean tourists; and (3) South Korean tourists had higher travel expenditure than others, but felt less satisfaction with travel services, which can be regarded as inefficient. Tourists from other countries had lower travel expenditure, but had higher satisfaction levels, which was considered efficient based on input and output index. The findings could contribute to bridging the gap between research and practice in assessing the efficiency of inbound tourist service. Tourism practitioners should be aware of tourists' needs and interests, as these could be key fundamentals for improving tourists' satisfaction with Taiwan's service offerings.
\end{abstract}

Keywords: sustainable tourism; performance appraisal; technical efficiency; service quality

\section{Introduction}

The World Travel \& Tourism Council (WTTC, 2015) [1] estimates that travel and tourism in 2014 was directly and indirectly responsible for generating a significant $9.8 \%$ of world GDP, $9.4 \%$ of total employment and $4.3 \%$ of world total investment. Tourism has been a significant development strategy for many countries to maintain regional development [2,3]. The number of inbound tourists to Taiwan increased from 2.36 million in 1996 to 10.69 million in 2016, reaching the highest level in the past two decades [4]. Taiwan was ranked 32nd among 141 countries [5], and advanced 4 places compared with its ranking in 2011, demonstrating the rapid growth of Taiwan's tourism industry. Tourism companies should constantly improve operating efficiency, of which service quality is the most important competitive advantage for maintaining customer loyalty to improve repurchase intention due to diversified content in the tourism industry [6]. However, it is difficult for consumers to determine a tourism service or value before purchasing or experiencing them because of the nature 
of tourism services [7-9]. Other factors such as supply and demand, seasonal fluctuations, and service experience will affect the consumer decision making process, resulting in increased satisfaction and loyalty, or inconsistency.

Several studies have emphasized the role of service quality on the consumer's perceived value and post-purchase behavior $[10,11]$. Previous research has claimed that the evaluation of service quality should depend not only on its input-output ratio, but also on other input-output ratios such as waiting time and unreasonable prices, which cause dissatisfaction [12]. Service quality is difficult to define or observe through measures such as the real quantity of banking services [13]; therefore, other factors or variation should be considered during the estimation process. Some agencies rely on proxies for difficult-to-measure service outputs, for instance, banking services are proxied by labor hours in banking and the number of ATMs or hours billed to overcome the deficiency of the measurement $[13,14]$. Moreover, service quality could serve as an indicator that policy makers use to integrate incomplete, non-quantified data into informative data [15]. To fill the gap and prevent potential biases when estimating service quality, Charnes, Cooper, and Rhodes (1978) [16] (CCR) promoted the Farrell's (1957) [17] efficiency evaluation and developed the widely used Data Envelopment Analysis (DEA) to evaluate the relative efficiency of management and scientific assessment methods. The standard DEA models will improve its effectiveness with the use of the methodological extensions [18]. Furthermore, the DEA is a multi-factor productivity model for the purpose of evaluating the relative efficiencies of a homogenous set of decision making units (DMUs) [19] and handles multiple inputs and outputs of the performance evaluation method [20], in line with an ideal quantitative assessment of the performance model [21]. In recent years, DEA has been widely used in tourism research [22-33].

This study proposes a performance appraisal of tourism service quality in Taiwan with DEA using input and output constructs. The input measure includes the average expenditure per day per person, average accommodation cost, and the average length of stay; the output measure is overall satisfaction with travel service measured by a five-point Likert scale. An evaluation model and its indicators were used to comprehensively evaluate service quality perceived from domestic visitors in Taiwan. Based on theoretical and empirical analysis, suggestions to improve tourism service quality and to enhance enterprise competitiveness are made. The remainder of this paper proceeds as follows. In Section 2, we review the literature on Service Quality and Data Envelopment Analysis (DEA). Section 3 describes our research methodology, including data collection and measurement. Our data analysis procedures, using DEA, are provided in Section 4. Section 5 presents discussions and conclusions based on the empirical results, and we conclude with limitations and suggestions for future research.

Based on above discussion, this study has potential contributions by extending the body of knowledge in assessing the efficiency of inbound tourist services, including the integration of the economic principles of inputs and outputs with the use of the DEA approach; the adoption of the optimal input and output indicators for the evaluation of tourism service quality as well overall satisfaction with travel services and products. Additionally, drawing upon past research, this study possessed certain potential strengths. First, this study developed an improved model for the evaluation of tourism service quality by using a systematic analysis approach based on "relative efficiency evaluation." Essentially, this study used the linear programming to determine the validity of assessing tourism service quality. This approach was not related to the numerical values of inputs and outputs; thus, subjective errors in decision weighting could be effectively avoided. Next, this study conducted a holistic review to identify three input indicators of the time and monetary costs of the consumption of tourism services and products from tourists' perspectives; and one output indicator of tourist's overall satisfaction with travel services and products. Last, service quality is regarded as a critical dimension affecting customer perceived value and loyalty. This study constructed an integrated DEA model to assess service quality and satisfaction/dissatisfaction between different nationalities of groups, which have been considered effective predictors of revisit intentions in the tourism service industry [34]. 


\section{Literature Review}

\subsection{Service Quality}

Service quality is the extent of customer needs and expectations [35]. Compared to the quality of physical goods, service is an abstract and elusive concept because its characteristics are intangible, synchronized (not separable), heterogeneous, and perishable. The customer perceived service-quality evaluation model was first proposed to compare service quality perception prior to and after receiving services [36]. The service quality gap model (PZB model) was then proposed to compare service quality between expected customer services and actual service [37,38]. Namely, service quality is consumer satisfaction with service, and satisfaction depends on the disparity between actual service and the consumer's original expectation [39]. Service quality must be assessed within the process of delivering service and often occurs when customers contact with employees. The difference between customer service expectations and perceived service perception is expressed as service quality = cognitive services - service expectations [37,40,41].

Service quality consists of three dimensions: physical quality, enterprise quality, and interactive quality. Physical quality is the service from equipment and buildings; enterprise service is the impression and image of the enterprise; interactive quality is the interaction between employees and customers and among customers [42]. Services should be provided to meet consumer expectations [43] and actual cognition after receiving services [35]. Moreover, service quality in the retail industry is categorized into three basic types: search quality, experience quality, and credibility quality [44]. Customer perception of service quality includes process quality and output quality [45]. Process quality is customers' subjective evaluation of service during the service process; output quality measures customer service experiences [45]. Five well known dimensions of service quality as advocated by Parasuraman et al. (1985) [37] include tangibles, responsiveness, reliability, empathy, and assurance. Parasuraman et al. (1985) [37] proposed SERVQUAL as an evaluation method composed of two parts: one measures customer service-quality expectations in a certain category, and the other investigates the customers' evaluation of service quality levels. The SERVQUAL scale is the primary basis for measuring service quality in many studies based on consumers' expectations of service quality and perceived service quality [46]. The follow-up researchers have revised this measurement and developed the SERVPERF scale of service performance perceptions identified by consumers [47,48]. Specifically, service was regarded as the core for SERVPERF performance evaluation, without regard to the effect of customer expectations on evaluating service quality by service performance. Their study results demonstrated that SERVPERF is more effective than SERVQUAL's, with calculating weight, to assess service quality and reflect perceived service quality directly [47]. Based on the assumption that tourism is intangible and consumer-oriented, this study measures service quality directly from customer cognitive assessment to evaluate tourism service quality.

\subsection{Data Envelopment Analysis (DEA)}

Farrell (1957) [17] developed Data Envelopment Analysis (DEA) with a price-wise-linear hull approach to frontier estimation. DEA is a linear programming methodology for measuring production and scale efficiencies. Overall technical efficiency is multiplied by two and represents only an input structure. Farrell (1957) applied linear programming to estimate an empirical production technology frontier and measured the efficiency of decision-making units (DMUs) when the production process presents a structure of multiple inputs and outputs. The advantage of this method is DEA's ability to accommodate multiple inputs and outputs and take the returns to scale in calculating efficiency; the concept of increasing or decreasing efficiency is allowed based on size and output levels. DEA is used in productive efficiency to measure DMUs with equal conditions to obtain the highest efficiency and to depict production functions in the input and output combinations of a firm. This function can achieve the maximum output with any possible combination of inputs and form a production technology frontier. DEA's performance efficiency is divided into constant return to scale (CRS) or 
variable return to scale (VRS). CRS refers to increased output with the same proportional change, but the production scale not affecting efficiency. VRS refers to increased output with a different proportional change, the scale of production increasing with non-fixed ratio relations, and the production scale affecting efficiency.

Prior literature analyzes tourism destination competitiveness through efficiency analysis, which means the relation between resources used and results obtained. Parametric and nonparametric approaches such as, respectively, stochastic frontier analysis (SFA) and DEA are useful tools to implement efficiency analysis. Previous research used SFA and DEA for the evaluation of tourism efficiency [49-51]. The DEA model analyzed the styles and efficiency of international tourist hotels in Taiwan [52]; assessed the impact of ecommerce on hotel performance [53]. Prior study adopted SFA and DEA the efficiency ratio of 31 hotels in the tourism management department, and the result showed that DEA more clearly identified inefficient employees compared to Anderson's SFA [23]. The one-stage SFA [54] and the Malmquist Productivity index (MPI) [55] estimated the technical efficiency of 66 international tourist hotels in Taiwan in 1992 2002. The findings revealed that managerial efficiency of the international tourist hotel industry has improved gradually and attributed productivity growth to efficiency gains, not the effects of technical progress. The CCR model was used to estimate manager performance in 54 guesthouses as the assessment unit in the United States in1993, evaluating performance by both the measured variable and by service quality with non-measured indicators [29]. The CCR model also measured the operation performance of international tourist hotels in Taiwan, showing that performance appraisal in the food and beverage department is better than that for the customer service representatives, and that the international-chain hotels are better than those that are independently operated [30]. Competitive efficiency in the hotel market can be evaluated by the CCR model of DEA and cluster analysis [32], which were applied with the super-efficiency and MPI to assess Taiwan's international tourist hotels from 1994 to 1998. The findings showed that the scale of international-chain hotels is more efficient than non-international chain hotels [28]. The BCC model was applied to analyze 50 international tourist hotels in Taiwan and also found that international-chain tourist hotels are more efficient than non-international-chain hotels [22]. The model assessed the operation performance of 42 hotels in Portugal, where state-run hotels have higher performance levels [31]. The CCR and BCC of DEA models examined hotel operator efficiency in Africa [24] and analyzed the performance appraisals of 48 hotels in the United States in 1994 [26]. Due to poor technical efficiency and scale efficiency, the results show that overall efficiency for hotel value is only $42 \%$. The CCR of DEA and the BCC models analyzed the operating efficiency of 25 hotels in 2000 and found that four of them were efficient [33]. In short, DEA is a tool for efficiency evaluation. DEA calculates production with a mathematical programming model, rendering unnecessary the default function and parameters of the function. DEA simultaneously handles multiple input and output items in various units to obtain the production frontier rather than the mean, and separately identifies relative efficiency and relative ranking in each of the relative efficient units, contrasted to the traditional regression method. The results of operations provide not only learning resources for using the DMUs, but also specific references or information to tourism authorities. Therefore, DEA is the most appropriate assessment method to analyze tourism service-quality performance in this study.

\section{Methods}

DEA efficiency assessment can be divided into technical efficiency, scale efficiency, pure technical efficiency, allocation efficiency, and overall efficiency. Enhancing overall efficiency in the DMU requires optimal technical efficiency. However, technical efficiency becoming optimal in the decision-making unit does not ensure overall efficiency optimization. In some cases, a DMU is limited on controlling inputs, making it difficult to determine the unit cost of inputs, which in turn causes difficulties in determining overall efficiency and allocative efficiency. Therefore, technical efficiency generally measures only performance of the DMU and so is used to evaluate the quality performance index of tourism service in this study. 


\subsection{CCR Model}

The CCR model is the basic DEA model. This model is an efficient evaluation model for multiple inputs and outputs, and the evaluation unit has constant returns to scale in assumptions and draws an isoquant from appraisal earnings to find the evaluated unit's maximum output efficiency. This forms the efficient frontier, which is used to assess organization efficiency from DMUs.

\subsection{BCC Model}

Banker, Charnes, and Cooper (1984) [56] modified the BCC model with fewer restrictions on constant returns of scale. The BCC model measures not only production efficiency (PE), but also technical efficiency (TE) and scale efficiency (SE).

Selection of a DEA model is based on the purposes of analysis for user needs and the properties of input and output items. User analysis purposes should consider the goals of efficiency/effectiveness, static/comparative static, and improve/forecast. Efficiency is the relationship between inputs and outputs; therefore, general DEA can assess efficiency. Technical efficiency, scale efficiency, congestion, and the allocation efficiency model explain the efficiency evaluation results from diverse points of view for overall analysis. Chang, Hwang, and Cheng (1995) [57] proposed performance improvement as the goal for analyzing performance; therefore, the DEA model must input 1 instead.

Decision makers control input and output variables, divided into controllable variables and uncontrollable variables. In a typical input-output DEA model, decision makers assume the input and output variables. If input and output variables are exogenous, decision makers cannot control them and improve their values.

\subsection{DEA Mathematical Programming Formulation}

DEA describes the empirical evaluation of the relative efficiency of a DMU based on $\mathrm{S}(\mathrm{X} j, j=1,2 \ldots \ldots, s)$ inputs and $\mathrm{M}(\mathrm{Y} i, i=1,2 \ldots \ldots, \mathrm{m})$ outputs. To estimate for DMU-K, $V_{j}$ and $U_{i}$ represent output $i$ and input $j$ as the unknown weight for calculating the ratios of inputs and outputs to determine efficiency. Input-oriented and output-oriented are used to estimate the efficiency of each unit. The following shows the empirical input-oriented model to evaluate efficiencies of DMUs:

Model 1:

$$
\operatorname{Max}_{k}=\frac{\sum_{i=1}^{m} U_{i} Y_{i k}}{\sum_{j=1}^{s} V_{j} X_{j k}}
$$

Subject to:

$$
\begin{aligned}
& \frac{\sum_{i=1}^{m} U_{i} Y_{i k}}{\sum_{j=1}^{s} V_{j} X_{j k}} \leqq 1, U_{i} \geqq 0, V_{j} \geqq 0 \\
& (i=1,2,3, \ldots \ldots m ; j=1,2,3, \ldots \ldots s ; k=1,2,3, \ldots \ldots n) .
\end{aligned}
$$

Here,

K DMU

$\mathrm{h}_{k} \quad$ relative efficiency of DMU

$\mathrm{Y}_{i k} \quad i$ output of $k$ th DMU

$\mathrm{X}_{j k} \quad k$ output of $j$ th DMU

$V_{j}, U_{i} \quad$ weight of $i$ output of $k$ th DMU and $k$ output of $j$ th DMU

Because it is difficult to solve nonlinear programming in fraction programming having an infinite context, the denominator of the fraction is set to " 1 " and substituted into the constraints and converted into a linear programming model, as follows: 
Model 2:

$$
\operatorname{Max}_{k}=\sum_{i=1}^{m} U_{i} Y_{i k}
$$

Subject to:

$$
\begin{gathered}
\sum_{j=1}^{s} V_{j} X_{j k}=1 \\
\sum_{i=1}^{m} U_{i} Y_{i r}-\sum_{j=1}^{s} V_{j} V_{j r} \leqq 0 \\
U_{r} \geqq \zeta>0, V_{i} \geqq \zeta>0 \\
(i=1,2,3, \ldots \ldots m ; j=1,2,3, \ldots \ldots s ; k=1,2,3, \ldots \ldots n) .
\end{gathered}
$$

Under this assumption, the CCR model measures the relative efficiency of returns to scale under constant scale efficiency. Considering the technical efficiency of DMUs, this scale efficiency is not suitable for the CCR model. Therefore, Banker et al. (1984) [56] revised the CCR model. They substituted the $U_{k}$ item into the CCR model and production function eliminating the need to pass through the original point for the developed BBC model to measure technical efficiency and scale efficiency. The BCC model is divided into inputs and outputs oriented to the relative performance of "Inputs oriented" DMUs shown below:

$$
\operatorname{Maxh}_{k} \sum_{i=1}^{m} U_{i} Y_{i k}-U_{k}
$$

Subject to:

$$
\begin{gathered}
\sum_{j=1}^{s} V_{j} X_{j k}=1 \\
\sum_{i=1}^{m} U_{i} Y_{i k}-\sum_{j=1}^{s} V_{j} X_{j k}-U_{k} \leqq 0 \\
U_{i} \geqq \zeta>0, V_{i} \geqq \zeta>0 \\
(i=1,2,3, \ldots \ldots m ; j=1,2,3, \ldots \ldots s ; k=1,2,3, \ldots \ldots n) .
\end{gathered}
$$

Here,

k DMU

$\mathrm{h}_{k} \quad$ relative efficiency of DMU

$Y_{i k} \quad i$ output of $k$ th DMU

$\mathrm{X}_{j k} \quad k$ output of $j$ th DMU

$\zeta \quad$ Non-Archimedean small number

$V_{j}, U_{i} \quad$ weight of $i$ output of $k$ th DMU and $k$ output of $j$ th DMU

According to $U_{k}$, we investigated the scale of efficiency in decision units. If $U_{k}=0$, the production-based scale is constant production efficiency; and if $U_{k}>0$, under the optimal production environment, production will decrease. If $U_{k}<0$, under the optimal production environment, production will increase.

\subsection{Evaluating Objects}

Using DEA to evaluate efficiency, the DMUs should meet Golany and Roll's Criteria. DMUs must have the same goals, implement similar work, and operate the same input and output items in the same market. This research is based on the Tourism Bureau, Republic of China (Taiwan) reports published in the "2015 Survey of Travel by R.O.C. Citizens" and the "2015 Survey Report on Visitors' Expenditures and Trends in Taiwan" $[58,59]$. These indexes of the domestic and international travel and tourism market in Taiwan were used as research objects, and three input variables and one output variable, i.e., four variables altogether, met the above conditions for a DMU. 


\subsection{Retrieval Performance Indexes}

In view of volatility and differences in tourism service quality, its contents and denotations are difficult to define. Therefore, during the selection of input and output indexes for the model of tourism service quality evaluation, priority must be given to relatively comprehensive and expressive indexes. The data of all indicators should be comparable in order to improve the persuasiveness of the conclusions related to tourism service quality evaluation.

\subsection{Selection of Input Indexes}

Tourists spend considerable cost and time to obtain the right travel services and products. Therefore, the index of the tourism service-quality evaluation model includes tourist expenditures and time spent for tourism service and products. In this study, "average expenditure per person per day" and "average accommodation cost" were the key indexes for measuring cost, and "average length of stay" was the key index for measuring time cost, which is explained as follows.

First, the main reason for selecting these two key input indexes "average expenditure per person per day," and "average accommodation cost" to measure monetary costs was based on the 2015 Survey of Travel by R.O.C. Citizens and 2015 Survey on Foreign Tourists' Consumption and Tendency in R.O.C. These statistical data measure tourists' expenditures during the consumption of tourism services and products using the following statistical indexes: average expenditure per person per day and average accommodation cost for both domestic and inbound tourists. Considering the differences between the statistical indexes for sampling surveys between domestic and inbound tourists, therefore, this study selected "average expenditure per person per day" and "average accommodation cost" as the indexes in order to ensure the objectivity and accuracy of assessing service quality in the travel and tourism industry. Second, the "average length of stay" was chosen as the input index for measuring the time costs based on the statistical data described above for the same reason as that for the input indexes measuring monetary costs. To conclude, this study selected average expenditure per person per day, average accommodation cost, and average length of stay as three input indexes for the evaluation of tourism service quality. These input indexes allowed for a direct comparative analysis of different tourists to be conducted. Furthermore, a certain correlation exists between all indexes.

\subsection{Selection of Output Indicators}

The tourism service quality evaluation model assumes that the evaluation of tourism service quality is a psychological motivation and subjective perception. Therefore, the output index of the tourism service quality evaluation model should include the psychological expectations tourists have of tourism service quality and tourists' perception of actual tourism service quality. However, this study selected only the tourists' perception of actual tourism service quality as an output index, and under the DEA model, tourists' psychological expectations of tourism service quality were not selected. Selecting appropriate output indexes includes the following requirements: (1) obtaining the value of each output in all decision units, with a positive value; (2) the output indexes must reflect the interests of the analysts and DMUs for assessing the comparative effectiveness of related elements; (3) considering the principle of efficiency, larger output values are better [26]. Tourists' psychological expectation of quality service is difficult to quantify, and subjective measures are difficult to obtain. In summary, tourism service quality cannot fully meet the three requirements of tourist psychological expectations; therefore, this study referred to the 2015 Survey of Travel by R.O.C. Citizens and the 2015 Survey on Foreign Tourists' Consumption and Tendency in R.O.C. published by Tourism Bureau, Ministry of Transportation and Communications (2015) [58] to evaluate tourists' overall satisfaction (\%) with tourism services and products provided in Taiwan based on traveling convenience (convenient transportation to Taiwan, convenient transportation within Taiwan, convenient customs clearance process, convenient access to traveling information, and convenient communication facilities), internalization of the tourism environment (friendly attitudes among Taiwanese citizens, good verbal communication in the traveling 
environment, and ease of understanding road signs and public facilities announcements), and safety of the environment (good public security, safe accommodation facilities, safety of recreational facilities, and good food hygiene). Tourists' perceived satisfaction with tourism service quality was set as the output index.

\section{Results}

According to the statistical data issued by Tourism Bureau, Ministry of Transportation and Communications (2015) [58], 10,439,785 tourists came to visit Taiwan in 2015; this number hit a new record, being $5.34 \%$ higher than the 9,910,204 travelers in 2014. The number of tourists and growth rate for the four main sources of tourists were as follows: China-4,184,102 (4.94\%), Japan-1,627,229 (-0.46\%), Hong Kong and Macao-1,513,597 (10.02\%), and South Korea-658,757 $(24.84 \%)$. Furthermore, the number of foreign and domestic tourists in Taiwan reached 178,524,000, marking a $14.25 \%$ growth as compared to the year 2014. The average number of travel trips per person in Taiwan was 8.50 (higher than 7.47 in 2014). As Dyson et al. (2001) [60] suggested, the number of DMUs has to be at least 2* (number of input items * number of output items) to achieve a reasonable level of discrimination. Four variables were used in this study, including three input variables (average expenditure per person per day, average lodging expenditure, average length of stay) and one output variable (overall satisfaction with travel services) as seen in Table 1. Moreover, six DMUs were estimated in this study, including "domestic tourists," "tourists from Japan," "tourists from Mainland China," "tourists from South Korea," "tourists from Hong Kong and Macau," and "tourists from other countries."

Table 1. The input and output data.

\begin{tabular}{|c|c|c|c|c|c|c|c|}
\hline \multicolumn{2}{|c|}{ Efficient Decision-Making } & $\begin{array}{l}\text { Domestic } \\
\text { Tourists }\end{array}$ & $\begin{array}{l}\text { Tourists } \\
\text { from } \\
\text { Japan }\end{array}$ & $\begin{array}{l}\text { Tourists from } \\
\text { Mainland } \\
\text { China }\end{array}$ & $\begin{array}{l}\text { Tourists } \\
\text { from South } \\
\text { Korea }\end{array}$ & $\begin{array}{l}\text { Tourists from } \\
\text { Hong Kong } \\
\text { and Macau }\end{array}$ & $\begin{array}{l}\text { Tourists } \\
\text { from Other } \\
\text { Countries }\end{array}$ \\
\hline $\begin{array}{l}\text { Input } \\
\text { index }\end{array}$ & $\begin{array}{l}\text { Average accommodation } \\
\text { cost }\end{array}$ & $\$ 55.90$ & $\$ 97.32$ & $\$ 43.67$ & $\$ 92.20$ & $\$ 69.49$ & $\$ 67.02$ \\
\hline $\begin{array}{l}\text { Output } \\
\text { index }\end{array}$ & $\begin{array}{l}\text { Overall satisfaction with } \\
\text { travel services (traffic, } \\
\text { entertainment, shopping) }\end{array}$ & $97.4 \%$ & $90.6 \%$ & $98.7 \%$ & $73.3 \%$ & $93.4 \%$ & $97.0 \%$ \\
\hline
\end{tabular}

Note: \$ means US dollar.

The DEA model assesses the relative efficiency between efficiency values rather than absolute values of DMUs; efficiency values closer to 1 express higher relative efficiency value. To calculate technical efficiency, this study used DEA-SOLVER software and the CCR model. This study used the BCC model to calculate simple technical efficiency in DMUs and scale efficiency. The tourism industry input items were maximized or minimized depending upon whether the input variables were used efficiently in the investment year through simple technical efficiency. Through scale efficiency, the yearly output and input ratios in the tourism industry were appropriate to achieve maximum productivity.

The results in Table 2 show that for domestic tourists, other foreign visitors (i.e., not Japanese, South Korean, Chinese, and Hong Kongers and Macanese), $\theta<1,000,000$ of South Korean tourists, Japanese tourists, and Chinese tourists, and $S_{j}^{-} \neq 0, j=1,2,3, S_{i}^{+} \neq 0$, which is neither a weak nor highly efficient DEA. That is, the tourism service quality in Taiwan did not satisfy all tourists. The smaller value of $\theta$ present in tourism service quality satisfaction for tourists decreased. Tourists in $\theta<1,000,000$ would proportionately reduce their consumption of tourism services and products. However, improving tourism services through quality control can improve tourist satisfaction. 
Table 2. Performance analysis.

\begin{tabular}{cccccc}
\hline Decision-Making Unit (DMU) & $\boldsymbol{\theta}$ & $\boldsymbol{S}_{\mathbf{1}}^{-}$ & $\boldsymbol{S}_{\mathbf{2}}^{-}$ & $\boldsymbol{S}_{\mathbf{3}}^{-}$ & $\boldsymbol{S}_{\mathbf{3}}^{+}$ \\
\hline Domestic tourists & 0.908 & 0 & 116.755 & 0 & 0 \\
\hline Tourists from Japan & 0.527 & 709.565 & 0 & 0 & 1.673 \\
\hline Tourists from Mainland China & 0.864 & 7032.656 & 274.336 & 0 & 3.966 \\
\hline Tourists from South Korea & 0.473 & 0 & 0 & 0 & 19.454 \\
\hline Tourists from Hong Kong and Macau & 0.815 & 6732.256 & 102.275 & 0 & 2.874 \\
\hline Tourists from other countries & 0.746 & 5036.165 & 60.393 & 0 & 0
\end{tabular}

Note: $S_{i k}^{-}$means the slack variable of input index; $S_{r k}^{+}$means the surplus variable of output index; $\theta$ means the estimated DMU of the reduced percentage of the all inputs.

The evaluation model constructed in this study treats tourists as DMUs, and quantitatively analyzes the relationship between inputs and outputs through their consumption of products and services. Because output decisions are based on inputs, the analyses of the empirical results demonstrate that the best focus is on the consumption process input. Analyzing input cost, the difference between tourist groups is more obvious, and this phenomenon directly affects their perception of actual tourism service quality.

Among domestic tourists, the surplus input is in tourism services and products spending in the tourism industry per person per day. $S_{2}^{-}=116.755$, indicating that the average spending per domestic traveller per day is not efficient, but it can be reduced proportional to the cost, with the same quality of services and products as the tourism industry currently offers. Compared with domestic tourists, all foreign tourist spending on products and services is not ideal. Among all foreign tourists, the $\theta$ value averages $(\theta=0.746)$, and is below 1 for each tourist nationality: Korean, $\theta=0.473$; Japanese, $\theta=0.527$; Hong Kongese and Macanese, $\theta=0.815$; Chinese, $\theta=0.864$. The lower the $\theta$ value, the lower the satisfaction with service quality efficiency in Taiwan.

The $\theta$ values for Hong Kongese and Macanese tourists and Chinese tourists are between 0.8 and 1 , with higher input efficiency, compared with those of tourists from other countries. The $\theta$ value range between tourists from other countries and Chinese tourists is small, which indicates a similar evaluation of satisfaction efficiency for service quality, and a similar residual amount of input costs. Excess variables in Chinese tourists are $S_{1}^{-}=7032.656, S_{2}^{-}=274.336$, and $S_{3}^{-}=0$, and for Hong Kongese and Macanese tourists such variables are $S_{1}^{-}=6732.256, S_{2}^{-}=102.275$, and $S_{3}^{-}=0$, indicating that average accommodation cost and average expenditure per person per day are not high, which could reduce cost but obtain the same quality of services and products based on the percentage of $\theta$ values. The $\theta$ value of Japanese tourists is lower than the $\theta$ values of tourists from other countries and Chinese tourists, and higher than only that of Koreans. The low $\theta$ value of Japanese tourists is mainly due to low efficiency on their investment in average accommodation cost. The excess variable of Japanese tourism is $S_{1}^{-}=709.565$. The $\theta$ value of South Korean travellers is the lowest, indicating that their evaluation of tourism services quality in Taiwan expresses the most dissatisfaction. The $\theta$ value of Korean tourists $=0.473, S_{1}^{-}=0, S_{2}^{-}=0, S_{3}^{-}=0, S_{3}^{+}=19.454$. Compared to other travellers, their input efficiency is not high because service quality in Taiwan does not meet their needs.

South Korean, Japanese, Hong Kongese and Macanese and Mainland China tourists all paid a higher proportion of expenses with dissatisfaction for transportation, entertainment, and shopping in the Taiwan tourism industry. However, the output efficiency for Japanese $\left(S_{3}^{+}=1.673\right)$, Hong Kongese and Macanese $\left(S_{3}^{+}=2.874\right)$ and Chinese tourists $\left(S_{3}^{+}=3.966\right)$ is high. Input and output asymmetry directly affects the overall perception of products and services and causes foreign travellers to give a dissatisfied evaluation of service quality and technical efficiency provided by the Taiwanese tourism industry.

In sum, by employing DEA of the CCR model and BCC model, the empirical analysis of estimation of the technical efficiency (TE) revealed the following: (1) The average score of TE for domestic tourists 
is 0.908 , which is quite efficient, indicating that the overall domestic tourism market is competitive, but there is still room for improvement of tourism services; (2) Mainland Chinese tourists had the highest score (TE score $=0.864$ ) among all foreign tourists, followed by Hong Kong and Macau tourists (TE score $=0.815)$, tourists from other countries (TE score $=0.746)$, Japanese tourists (TE score $=0.527$ ), and Korean tourists (TE score $=0.473$ ). Above assessment results show that the overall satisfaction with travel services perceived by inbound tourists in Taiwan is not efficient; and (3) The results demonstrate that South Korean tourists spent a higher proportion of money on travel expenditure (with a total of $\$ 299.98$ per person) than others, but felt less satisfaction $(73.3 \%)$ with travel services (traffic, entertainment, and shopping) which can be regarded as inefficient; conversely, tourists from other countries had lower travel expenditure (except for Japanese tourists), but had higher satisfaction levels, which was considered efficient based on input and output index.

\section{Conclusions and Suggestions}

\subsection{Conclusions}

Service quality is regarded as a critical dimension that affects customer perceived value and loyalty [45]. This study used DEA to evaluate the efficiency of the input and output indicators among domestic and inbound tourists to provide information or reference for enhancing tourism service quality based on the empirical results. Understanding tourists' perceptions of service quality and satisfaction can be important in helping tourism industries identify weaknesses and deficiencies and develop strategies for improvements. This case study demonstrate the application of DEA to estimate Taiwan tourism service quality in which the asymmetric inputs and outputs indicators could predict tourists' overall satisfaction with service quality. Based on the findings, there is still need for improving the efficiency of the input and output index among inbound tourists (particularly the South Korean and Japanese tourists). It is suggested to seek a balance between costs and satisfaction based on the efficiency of the input and output index. Customer-oriented service quality is necessary for Taiwan tourism organization that desires to better understand its targeted tourists and effectively manage a tourist service. The case study specially established the models of DEA to connect tourists' traveling cost and their satisfaction of tourism service quality. Compared to most research adopting DEA models with the data only from suppliers of the industry, this study supports the offerings of public/private tourism services to increase tourists' satisfaction and to enhance tourists' traveling efficiency through improving the quality of tourism services. The offerings, for instance, could enhance tourism service quality by providing employee training programs for serving South Korean tourists or providing traveling information using Korean, both of which could improve South Korean tourists' satisfaction and their traveling efficiency. To improve tourists' perceptions of the tourism service quality, tourism authorities or policy-makers should set standards to suit the tourists, deliver the tourists' expected standard of service among main inbound tourists or countries, and to control, evaluate and review for quality development and improvement [61] for the future direction of Taiwan inbound tourism.

\subsection{Limitations of the Research}

DEA is a non-parametric technique, which can be used for evaluating efficiency by considering several variables simultaneously. Unlike the parametric counterpart, non-parametric techniques do not rely on assumptions on the distribution of variables, eliminating the requirement for extra constraints. As an example, regression analysis usually asks for normal distribution of the variables, but there is no such limitation for the DEA technique. However, some limitations of DEA still need to be addressed in this study. The first limitation is the selection and adaptation of the variables (indicators). This study mainly adopted service quality which can be regarded as one means of assessing inbound tourist service. Second, the efficiency evaluated by DEA is a relative value, rather than an absolute one, leading to relatively high sensitivity of DEA. For example, compared to regression analysis, an erroneous outlier could greatly affect the DEA result, but the impact on regression analysis is relatively lower, 
owning to the averaging computation in the regression analysis. Third, the efficiency evaluated by DEA could be quite different when the scope of the data changes. In contrast, the result of the regression analysis is relatively consistent as long as random sampling is applied. Last, regression analysis provides the information on confidence interval which is not available in DEA; control variables cannot be included to confine the interference factors in DEA. Hence, DEA cannot perform hypothesis testing alone, as compared to regression analysis that can find the relationship between variables. However, DEA can be utilized for hypothesis testing by connecting other analysis methods. For example, the efficiency evaluated by DEA can be considered as a dependent variable; the independent variables are then included in the model for further regression analysis.

\subsection{Future Research}

Future researchers should pay attention to the selection of input and output indicators or variables, the examination of a wider respondent base across other countries, and the measure for reliability of efficient DMUs. In order to reduce the concern about using only few variables adopted from secondary data in this study, future studies could evaluate the well-chosen (e.g., service quality of hotels), representative variable, or integrating variable from different sources to represent tourists' satisfaction. Moreover, future studies can conduct longitudinal observations and compare data at different time to gain a better understanding of overall satisfaction with respect to tourism service quality in Taiwan.

Author Contributions: Four co-authors had together contributed to the completion of this article. H.-S.C. was the first author analyzing the data and drafted the manuscript; B.-K.T. contributed to reviewing the manuscript and revising the results and conclusion; G.-B.L. contributed to reviewing and revising the literature, results and conclusion; and C.-M.H. acted as corresponding author on their behalf throughout the revision and submission process.

Conflicts of Interest: The authors declare no conflict of interest.

\section{References}

1. World Travel \& Tourism Council (WTTC). The Authority on World Travel \& Tourism: Ravel \& Tourism Economic Impact 2015. Available online: https:// zh.wttc.org/-/media/files/reports/economic-impactresearch/regional-2015/world2015.pdf (accessed on 1 June 2018).

2. Dodds, R.; Butler, R. Barriers to implementing sustainable tourism policy in mass tourism destinations. Tourismos 2010, 5, 35-54.

3. Brida, J.G.; Risso, W.A. Tourism as a determinant of long-run economic growth. J. Policy Res. Tour. Leis. Events 2010, 2, 14-28. [CrossRef]

4. Ministry of Transportation and Communication. 2016 Visitor Arrivals by Purpose of Visit. Available online: http://stat.motc.gov.tw/mocdb/stmain.jsp?sys=100\&funid=a7101 (accessed on 28 May 2017).

5. World Economic Forum. The Travel \& Tourism Competitiveness Index Ranking 2015. Available online: http:/ / reports.weforum.org/travel-and-tourism-competitiveness-report-2015/index-results-the-traveltourism-competitiveness-index-ranking-2015/ (accessed on 12 June 2017).

6. Imrie, B.C.; Durden, G.; Cadogan, J.W. Towards a conceptualization of service quality in the global market arena. Adv. Int. Mark. 2000, 10, 143-162.

7. Kwun, J.W.; Oh, H. Effect of brand, price, and risk on consumers' value perceptions and behavioral intentions in the restaurant industry. J. Hosp. Leis. Mark. 2004, 11, 31-49. [CrossRef]

8. Sweeney, J.C.; Soutar, G.N. Consumer perceived value: The development of a multiple item scale. J. Retail. 2001, 77, 203-220. [CrossRef]

9. Zeithaml, V.A. Consumer perceptions of price, quality, and value: A means-end model and synthesis of evidence. J. Mark. 1988, 52, 2-22. [CrossRef]

10. Hu, H.H.; Kandampully, J.; Juwaheer, T.D. Relationships and impacts of service quality, perceived value, customer satisfaction, and image: An empirical study. Serv. Ind. J. 2009, 29, 111-125. [CrossRef] 
11. Su, L.; Swanson, S.R.; Chen, X. The effects of perceived service quality on repurchase intentions and subjective well-being of Chinese tourists: The mediating role of relationship quality. Tour. Manag. 2016, 52, 82-95. [CrossRef]

12. Fisk, R.P.; Brown, S.W.; Bitner, M.J. Tracking the evolution of the services marketing literature. J. Retail. 1993, 69, 61-103. [CrossRef]

13. Boyd, J.; Banzhaf, S. What are ecosystem services? The need for standardized environmental accounting units. Ecol. Econ. 2007, 63, 616-626. [CrossRef]

14. Griliches, Z. Introduction to Output Measurement in the Service Sectors. In Output Measurement in the Service Sectors; University of Chicago Press: Chicago, IL, USA, 1992; pp. 1-22.

15. Govindan, K.; Rajendran, S.; Sarkis, J.; Murugesan, P. Multi criteria decision making approaches for green supplier evaluation and selection: A literature review. J. Clean. Prod. 2015, 98, 66-83. [CrossRef]

16. Charnes, A.; Cooper, W.W.; Rhodes, E. Measuring the efficiency of decision making units. Eur. J. Oper. Res. 1978, 2, 429-444. [CrossRef]

17. Farrell, M.J. The measurement of productivity efficiency. J. R. Stat. Soc. 1957, 120, 253-290. [CrossRef]

18. Podinovski, V.V.; Thanassoulis, E. Improving discrimination in data envelopment analysis: Some practical suggestions. J. Prod. Anal. 2007, 28, 117-126. [CrossRef]

19. Talluri, S. Data envelopment analysis: Models and extensions. Decis. Line 2000, 31, 8-11.

20. Zbranek, P. Data envelopment analysis as a tool for evaluation of employees' performance. Acta Oecon. Inform. 2013, 16, 12-21. [CrossRef]

21. Song, M.L.; An, Q.; Zhang, W.; Wang, Z.; Wu, J. Environmental efficiency evaluation based on data envelopment analysis: A review. Renew. Sustain. Energy Rev. 2012, 16, 4465-4469. [CrossRef]

22. Aissa, S.B.; Goaied, M. Determinants of Tunisian hotel profitability: The role of managerial efficiency. Tour. Manag. 2016, 52, 478-487. [CrossRef]

23. Amin, M.; Yahya, Z.; Ismayatim, W.F.A.; Nasharuddin, S.Z.; Kassim, E. Service quality dimension and customer satisfaction: An empirical study in the Malaysian hotel industry. Serv. Mark. Q. 2013, 34, 115-125. [CrossRef]

24. Chang, Y.T.; Lee, S.; Park, H.K. Efficiency analysis of major cruise lines. Tour. Manag. 2017, 58, 78-88. [CrossRef]

25. Chang, Y.T.; Park, H.S.; Jeong, J.B.; Lee, J.W. Evaluating economic and environmental efficiency of global airlines: A SBM-DEA approach. Transp. Res. Part D Transp. Environ. 2014, 27, 46-50. [CrossRef]

26. Chang, Y.T.; Zhang, N.; Danao, D.; Zhang, N. Environmental efficiency analysis of transportation system in China: A non-radial DEA approach. Energy Policy 2013, 58, 277-283. [CrossRef]

27. Huang, S.W.; Kuo, H.F.; Hsieh, H.I.; Chen, T.H. Environmental efficiency evaluation of coastal tourism development in Taiwan. Int. J. Environ. Sci. Dev. 2016, 7, 145-150. [CrossRef]

28. Shahin, A.; Shirouyehzad, H. Importance-performance analysis of service quality dimensions for the customer groups segmented by DEA. Int. J. Qual. Reliab. Manag. 2016, 33, 160-177. [CrossRef]

29. Shirouyehzad, H.; Lotfi, F.H.; Shahin, A.; Aryanezhad, M.B.; Dabestani, R. A DEA approach for comparative analysis of service quality dimensions with a case study in hotel industry. Int. J. Serv. Oper. Manag. 2012, 12, 289-308. [CrossRef]

30. Su, C.S. An importance-performance analysis of dining attributes: A comparison of individual and packaged tourists in Taiwan. Asia Pac. J. Tour. Res. 2013, 18, 573-597. [CrossRef]

31. Wu, J.; Yin, P.; Sun, J.; Chu, J.; Liang, L. Evaluating the environmental efficiency of a two-stage system with undesired outputs by a DEA approach: An interest preference perspective. Eur. J. Oper. Res. 2016, 254, 1047-1062. [CrossRef]

32. Yin, P.; Tsai, H.; Wu, J. A hotel life cycle model based on bootstrap DEA efficiency: The case of international tourist hotels in Taipei. Int. J. Contemp. Hosp. Manag. 2015, 27, 918-937. [CrossRef]

33. Zaman, M.; Botti, L.; Thanh, T.V. Does managerial efficiency relate to customer satisfaction? The case of Parisian boutique hotels. Int. J. Cult. Tour. Hosp. 2016, 10, 455-470. [CrossRef]

34. Kim, H.; Woo, E.; Uysal, M. Tourism experience and quality of life among elderly tourists. Tour. Manag. 2015, 46, 465-476. [CrossRef]

35. Mardani, A.; Jusoh, A.; Zavadskas, E.K.; Khalifah, Z. Application of multiple-criteria decision-making techniques and approaches to evaluating of service quality: A systematic review of the literature. J. Bus. Econ. Manag. 2015, 16, 1034-1068. [CrossRef] 
36. Grönroos, C. A service quality model and marketing implications. Eur. J. Mark. 1984, 18, 36-44. [CrossRef]

37. Parasuraman, A.; Zeithaml, V.A.; Berry, L.L. A conceptual model of service quality and its implications for future research. J. Mark. 1985, 49, 41-50. [CrossRef]

38. Parasuraman, A.; Zeithaml, V.A.; Berry, L.L. SERVQUAL: A multiple-item scale for measuring consumer perception of service quality. J. Retail. 1988, 64, 12-40.

39. Reichheld, F.F.; Sasser, W.E., Jr. Zero defection: Quality comes to service. Harv. Bus. Rev. 1990, 68, $105-111$. [PubMed]

40. Chan, A.; Hsu, C.H.; Baum, T. The impact of tour service performance on tourist satisfaction and behavioral intentions: A study of Chinese tourists in Hong Kong. J. Travel Tour. Mark. 2015, 32, 18-33. [CrossRef]

41. Choudhury, K. Service quality and customers' purchase intentions: An empirical study of the Indian banking sector. Int. J. Bank Mark. 2013, 31, 529-543. [CrossRef]

42. Churchill, G.A.; Surprenant, C. An investigation into the determinants of customer satisfaction. J. Mark. Res. 1982, 19, 491-504. [CrossRef]

43. Sweeney, J.; Armstrong, R.W.; Johnson, L.W. The effect of cues on service quality expectations and service selection in a restaurant setting: A retrospective and prospective commentary. J. Serv. Mark. 2016, 30, 136-140. [CrossRef]

44. Lehtinen, U.; Lehtinen, J.R. Service Quality: A Study of Quality Dimension; Service Management Institute: Helsinki, Finland, 1982.

45. Forsythe, P. Monitoring customer perceived service quality and satisfaction during the construction process. Constr. Econ. Build. 2015, 15, 19-42. [CrossRef]

46. Brown, T.J.; Churchill, G.A.; Peter, J.P. Improving the measurement of service quality. J. Retail. 1993, 69, 127-139. [CrossRef]

47. Cronin, J.J., Jr.; Taylor, S.A. Measuring service quality: A re-examination and extension. J. Mark. 1992, 56, 55-68. [CrossRef]

48. O'Cass, A. Achieving service quality through service innovation exploration-exploitation: The critical role of employee empowerment and slack resources. J. Serv. Mark. 2015, 29, 137-149. [CrossRef]

49. Assaf, A.G.; Dwyer, L. Benchmarking international tourism destinations. Tour. Econ. 2013, 19, $1233-1247$. [CrossRef]

50. Peypoch, N.; Solonandrasana, B. Aggregate efficiency and productivity analysis in the tourism industry. Tour. Econ. 2008, 14, 45-56. [CrossRef]

51. Assaf, A.G.; Tsionas, E.G. Incorporating destination quality into the measurement of tourism performance: A Bayesian approach. Tour. Manag. 2015, 49, 58-71. [CrossRef]

52. Sun, S.; Lu, W.M. Evaluating the performance of the Taiwanese hotel industry using a weight slacks-based measure. Asia Pac. J. Oper. Res. 2005, 22, 487-512. [CrossRef]

53. Shang, J.K.; Hung, W.T.; Lo, C.F.; Wang, F.C. Ecommerce and hotel performance: Three-stage DEA analysis. Serv. Ind. J. 2008, 28, 529-540. [CrossRef]

54. Chang, T.Y.; Hwang, S.N. The performance evaluation model for the international tourist hotel of Taiwan-the comparison of the grey relation analysis and data envelopment analysis. J. Tour. Stud. 2006, 12, 67-90.

55. Wang, Y.H.; Lee, W.F.; Wong, C.C. Productivity and efficiency analysis of international tourist hotels in Taiwan: An application of the stochastic frontier approach. Taiwan Econ. Rev. 2007, 35, 55-86.

56. Banker, R.D.; Charnes, A.; Cooper, W.W. Some models for estimating technical and scale inefficiencies in data envelopment analysis. Manag. Sci. 1984, 30, 1078-1092. [CrossRef]

57. Chang, P.L.; Hwang, S.N.; Cheng, W.Y. Using data envelopment analysis to measure the achievement and change of regional development in Taiwan. J. Environ. Manag. 1995, 43, 49-66. [CrossRef]

58. Tourism Bureau, Republic of China. 2015 Survey of Travel by R.O.C. Citizens. Available online: http:// admin.taiwan.net.tw/upload/statistic_eng/20160810/4ba2be7b-4a36-4392-8f97-2ffa4d6e3b32.pdf (accessed on 9 January 2017).

59. Tourism Bureau, Republic of China. 2015 Survey Report on Visitors Expenditure and Trends in Taiwan. Available online: http:/ / admin.taiwan.net.tw/upload/statistic_eng/20160810/746f0cac-3cfe-494e-8dd5ccf8e34477ce.pdf (accessed on 9 January 2017). 
60. Dyson, R.G.; Allen, R.; Camanho, A.S.; Podinovski, V.V.; Sarrico, C.S.; Shale, E.A. Pitfalls and protocols in DEA. Eur. J. Oper. Res. 2001, 132, 245-259. [CrossRef]

61. Drummond, S.; Yeoman, I. Measurement of Service Quality. In Quality Issues in Heritage Visitor Attractions; Frochot, I., Ed.; Butterworth: Oxford, UK, 2001; pp. 154-171. 